\title{
Khadijah (RA) an Ideal Wife: A Perfect Model and Example of Muslim Women
}

\author{
By Dr. Rashidah \\ International Islamic University Chittagong
}

Abstract- The marriage is not just an economical and physical arrangement of living together but a holy agreement, a gift of Allah, to lead a joyful life and carry on the lineage. The connection between them is not like as neighbors and friends; it is more excessive. Allah (SWT) explained in the Quran:

The sign of Allah is that He created mates for you from your selves to get tranquility in each other's, and $\mathrm{He}$ placed between them love and compassion (Al-Quran, 30: 21).

Husbands and wives must be well-mannered, pleasant, sympathetic, frank, helpful, reliable, well-wishing, loyal, and polite with one other. A good and virtuous wife is a most pleasure for a husband. Mother of the believers Khadijah (Ra) was dutiful, comfortable, and well-being of her husband to Prophet Muhammad (saw).

This paper aims to explore and highlight the Khadijah (Ra) works, activities, behavior, and manners as a righteous wife of Prophet Muhammad (saw) and investigate the probable measures for Muslim women from her family life. This paper is a theoretical study based on the biography of Khadijah (Ra) and Hadith of the Prophet (saw). Therefore, I strongly think that today the instructions, lessons, and teachings from Khadijah (Ra) family life are indispensable for Muslim Ummah to bring peace and happiness in the modern age.

Keywords: khadijah (Ra), ideal, model, example. muslim women.

GJHSS-A Classification: FOR Code: 130205p

Strictly as per the compliance and regulations of:

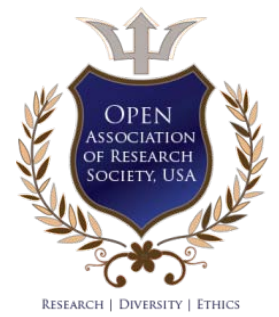

(C) 2019. Dr. Rashidah. This is a research/review paper, distributed under the terms of the Creative Commons AttributionNoncommercial 3.0 Unported License http://creativecommons.org/licenses/by-nc/3.0/), permitting all non-commercial use, distribution, and reproduction in any medium, provided the original work is properly cited. 


\title{
Khadijah (RA) an Ideal Wife: A Perfect Model and Example of Muslim Women
}

\author{
Dr. Rashidah
}

Abstract- The marriage is not just an economical and physical arrangement of living together but a holy agreement, a gift of Allah, to lead a joyful life and carry on the lineage. The connection between them is not like as neighbors and friends; it is more excessive. Allah (SWT) explained in the Quran:

The sign of Allah is that He created mates for you from your selves to get tranquility in each other's, and $\mathrm{He}$ placed between them love and compassion (Al-Quran, 30: 21).

Husbands and wives must be well-mannered, pleasant, sympathetic, frank, helpful, reliable, well-wishing, loyal, and polite with one other. A good and virtuous wife is a most pleasure for a husband. Mother of the believers Khadijah (Ra) was dutiful, comfortable, and well-being of her husband to Prophet Muhammad (saw).

This paper aims to explore and highlight the Khadijah (Ra) works, activities, behavior, and manners as a righteous wife of Prophet Muhammad (saw) and investigate the probable measures for Muslim women from her family life. This paper is a theoretical study based on the biography of Khadijah (Ra) and Hadith of the Prophet (saw). Therefore, I strongly think that today the instructions, lessons, and teachings from Khadijah ( $\mathrm{Ra}$ ) family life are indispensable for Muslim Ummah to bring peace and happiness in the modern age.

Keywords: khadijah (Ra), ideal, model, example. muslim women.

\section{INTRODUCTION}

A wife is an institution of the whole nation. Its root goes back to the beginning of the first man and woman Adam and Hawwa, the first woman of the world Hawwa was the wife of Adam (first man). A good and sound society depends upon the smallest unit that is a family; and a family builds by love, care, and cooperation between the husband and wife. It raises peace of mind and provides a secure atmosphere for the growth and progress of the whole human race. The most of the Prophet, including the last Prophet Muhammad (saw) practiced system of marriage. His first wife was Khadijah ( $R a)$, she is the perfect model, icon, example for Muslim women.

\section{il. Short Biography of Khadijah (RA)}

Khadijah (Ra) was born fifteen years before the year of the Elephant (Amul Fil) in 566 CE at Makkah. Her

Author: Assistant Professor, Islamic Studies Center for University Requirement Courses (CENURC) International Islamic University Chittagong,Bangladesh.e-mail: rashi.nawmy@gmail.com nickname was Ummul Hind and Ummul Kasim. She was famous by his surname "Tahira"(the sacred one), and Khadijah Al-Kubra (Khadijah the great). Her father, Khuwaylid ibn Asad wasa great businessman of Makkah. Her mother, Fatima bint Za'idah was a third cousin of Prophet Muhammad (saw) mother (Aj-Jahabi, 1990). She died in Ramadan, tenth year after the Prophet Hood. She buried in Jannatul Mualla in Makkah. The Prophet Muhammad (saw) feels grieffor the death of Khadijah, later Prophet (saw) called this year "Amul Hujon" (the year of sorrow). Here mentionable that the uncle of Prophet (saw) Abu Talib also died at the year of Khadijah's death year (Tabari, 1998).

\section{ili. The Dignity of Khadijah (RA.) IN ISLAM}

Khadijah (Ra.) was the first from companions of Prophet (saw) who get the glad tidings as to enter into Jannat (heaven). The Prophet Muhammad (saw) said her, "O Khadijah, here is Jibreel. He ordered me to say Salam to you and to inform you the glad of tiding of a home of pearl in Jannat (heaven) in which there will be no pain or toil." She responded Allah is the contributor to Salam. Peace is upon Jibreel and peace, and mercy of Allah be upon you" (Saheeh Muslim, Chapter: The virtues of companions, the Mother of the Believers).

Abdullah Ibn Abbas (RA) reported one day the Prophet (saw) drew four lines on the land and told, "Do you know the significance of these four lines? The companions of Prophet (saw) who were present there respectfully answered, Allah and his Prophet (saw) knows best. The Prophet (saw) said that those four lines meant the four most graceful and great women of the universe, they are, Khadija bint Khuwalid (Ra), Fatima bint Muhammad (saw), Mariam bint Imran and Asia bint Mazahim.

The wife of the Prophet (saw) Ayesha (Ra) feels jealous about Khadijah (Ra), although Khadijah (Ra) had died before her married to Prophet (saw). Ayesha (Ra) said,

"I never jealous any of the Prophet's wives as I jealous Khadijah (Ra), and I had not even seen her. The Prophet all the time remembered her. Whenever any sheep or goat slaughtered, He sent the choicest parts to Khadijah,s relatives and friends".

"The Prophet of Allah rarely went out of the home except mentioning Khadijah (Ra) and praising her, 
One day he said about Khadijah (Ra) at that time I feel jealous and said, was she not an old lady whom Allah has replaced for you with a better woman? He got angry and replied, "No, by Allah! He did not alternate her with other one. Because, Khadijah believed in my speech and work at what time people doubted in my mission, she helped me with her assets while men ignore me from their wealth, and Allah give me children from Khadijah (Ra) (Ayesha (Ra) said) and I said in my mind, "never shall I speak unfavorably of her again" (Saheeh Bukhaaree, The virtues of the Ansar).

\section{Khadijah (Ra) Marriage to Prophet (SAW)}

Khadijah (Ra) was a very successful merchant. She appointed others to business on her behalf for a commission. After she heard about the honesty and responsibility of Muhammad (saw), she offered Muhammad (saw) to do business on her promising gave to double from her usual commission. He agreed and left Makkah with the Khadijah's servant Maisarah. On this business trip, he had made a lot of profit for Khadijah. Maisarah informs Khadijah about the noble character and qualities of Muhammad after return from a business trip (Ibn Hisham, 1955). Before her marriage with Prophet Muhammad (saw), she married twice time. Her first husband was Abu Halah Malik bin Zararah Tamimi and the second husband was Atiq bin Aidah. By her first husband khadijah ( $\mathrm{Ra}$ ) had two children, Hind and Hala and by her second husband, he had a child Hinda. She refused many proposals of marriage after the death of her two husbands because she had no intent to marry a third time (Ibn Hajar, 1978). She changed her decision when she meets to Prophet Muhammad for her business transaction. She proposed the Prophet Muhammad (saw) through her friend Nafeesa to marry her. The Prophet Muhammad (saw) was delighted with the proposal, but he nonetheless first went to his uncles to ask their advice, they all settled that he should marry her (Ibn Saad, ND).

At the time of marriage Muhammad (saw) was twenty-five years old, and Khadijah was forty years old. She had two sons and four daughters by the Prophet Muhammad (saw). They are Qasim, Zainab, Ruqayya, Umme Kulsum, Fatima, and Abdullah (Ali Khan, 1983).

\section{First Muslim}

Khadijah (Ra) was the first female, or rather the first person, who believe Allah and His last Prophet Muhammad (saw) and believe in all that he receives from Allah by wahy (revelation) (Ibnul Asir, ND). She was also the first who hear revealed verses of the Quran from the Prophet Muhammad (saw) and after the Prophet (saw) first recite it. She was also the first person who acquires knowledge of prayer from Prophet (saw). One day, the Prophet Muhammad (saw) Came home after Jibreel trained him the rules of prayer. When Prophet (saw) told her of this, she said, "Just teach me how he trained you," the Prophet trained her. She then completed ablution as he did and prayed along with Prophet (saw) (Al-kandhalubhi, 1983).

\section{a) Sacrifice wealth in the way of Allah}

Allah said: Never will you attain the good (reward) until you spend in the path of Allah) from that which you love (Al-Quran, 3: 93).

Khadijah $(\mathrm{Ra})$ practiced this order of Allah by heart and soul. She gave the charge of her trade to Prophet Muhammad (saw), who also visited numerous places in Arabia, including Yemen and Bahrain, in connection with the trade missions. Khadijah (Ra) said her husband that all her property was his (Muhammad saw), so he could use just as he desire it. The messenger of Allah Muhammad (saw) invested her (Khadijah's) all property in the way of Allah (Ibn Hisham, 1955). Especially her financial support for confined period of Muslims in the valleys of Abu Talibis mentionable. Khadijah knew her husband's dreams and hopes, so to complete her husband's vision; she spared him the trouble of labor by giving ownership of her vast wealth. As a result, the Prophet Muhammad (saw) devoted all his time in the way of Allah. Allah reminded the Prophet (saw) of this favor as He said:

"Allahfound you poor then He prepared you self-reliant" (Al-Quran, 93: 8).

She also showed compassion to poor and needy Muslims. She was very kind to them (Ali Khan, $\mathrm{ND})$.

\section{b) Family life}

A peaceful family only set with a righteous, virtuous, and devoted woman. Khadijah (Ra.) was the first woman who obtained the credit to become the first wife of Prophet (saw) and the first Ummul Muminun (mother of the believers), and the Prophet's of Allah Muhammad (saw) did not marry any other woman until she died (Muhammad Ali Qutub, 2008).The respect, love, and admiration are complete the family relationship between Muhammad (saw) and Khadijah (Ra).

\section{c) Choosing a spouse based on morality}

A happy family life depends on husband-wife pure character and honesty. The family life of Khadijah (Ra.) and Prophet (saw) was full of pleased because both they have the same morals and manners, and their hearts also shared the same feeling. It described in the Prophet Hadith:

The most pleasure in life is a good, virtuous wife (Saheeh Muslim, The volume of Nursing; section: The greatest happiness of the earth is an honest wife).

Khadijah (Ra.) character and morality were so high that the Prophet (saw) entitled her as "the greatest 
amongst the women of this nation" (Abul Hasan AlBalajuri, ND). In selecting Khadijah (Ra) as a wife, Prophet Muhammad (saw) prefer her nobility and character. Because she was also one of those few, who lived an upright life even in the pre-Islamic time and saved herself from the indecent that was widespread in that time, so she was famous by the name of Tahira, which meaning one who is pure (Aj-Jahabi, 1990).

On the other hand, the character of Prophet (saw) was so high that he was polite and modest; liberal and noble; thoughtful and considerate; truthful and sincere. He liked the good and disliked the bad. Allah said in the Quran: And indeed you are of a moral character. (Al-Quran, 68:4)

\section{d) Careful mother}

There is a famous saying: "Who brings up a male, brings up a man, but who brings up a woman, brings up a generation." The most effective teacher for a man "Mother", a very famous quotation from Napoleon Bonaparte, "Give me a good mother, and I shall give you a great nation!" (https://www.azquotes.com/quote/).

Khadijah (Ra) was a caring mother. She gave her full contemplation on her children and family and took care of them properly. Khawla bint Hakeem said the Prophet (saw) after the death of Khadijah, Oh the Prophet of Allah! It seems you have been troubled for the demise of Khadijah. The Prophet (saw) then said, "Yes, she was the mother of the household and the caretaker of the family" (Muhammad Ali Qutb, 2008).

After the first revelation of Quran from Allah to Prophet Muhammad (saw) the wife of Prophet (saw) Khadijah (Ra) gathered their four daughters Zaynab, Ruqayyah, Umm Kulthum, and Fatima, She also gathered other two members of Prophet House Ali ibn Abi Talib and Zaid ibn Harith with them. Then she explained what had happened in the cave of Heera with Prophet (saw) and asked them would they believe in the message of Prophet Muhammad (saw) with seriousness and confidence. Without any hesitation this six-person, they stated their belief in Allah as their only creator and Muhammad as His messenger (Ibnul Asir, ND).

\section{e) Give console at the crisis and threat time}

The duty of a woman as a wife she must be careful about the consolation and well-being of her husband. She may neither annoy him nor offend his feelings. It's explained almighty Allah in the Holy Quran as the virtuous people desire, they pray:

Oh Allah, gift us from among our wives and children console to our eyes and build us a leader for the righteous (Al-Quran, 25: 74).

Ummul Muminin (mother of the believers) Khadijah (Ra) was an example of this verse. Because Khadijah (Ra) always support Prophet Muhammad (saw) physically and mentally before and after his Prophethood. After the first revelation of the wahy,
Prophet Muhammad (saw) was terrified and anxious. He came into Khadijah (Ra) and said: wrap to me! Wrap to me! So, she covered him, and when the panic left him, he informed Khadijah about what occurred in the cave of Heera and said: I fear for myself, Khadijah (Ra) replied: Never! By Allah, Allah will never abandon you, because you attach ties of family connection, you carry the troubles of the feeble, you provide to people what no one else can supply, you are hospitable to your guests and relatives, and you assist people who are troubled with calamities. Khadijah ( $\mathrm{Ra}$ ) relieved Prophet Muhammad (saw) by reminding him of his good virtues and quality (Saheeh Bukhari, the beginning of revelation).

\section{f) Asking advice from an honorable, honest person}

The angel Jibril came to Prophet Muhammad (saw) when he was in the cave of Heera and said: "Read," the Prophet (saw) replied, I am not able to read. Jibril pressed him to his breast number of times then the following verses said:

"Read in the name of your creator who shaped man from a clinging substance. Read, and your creator is the most benevolent, He taught by the pen, Taught man that which he knew not" (Al-Quran, 96: 1-5).

At this moment, the Prophet (saw) returned home with frightened, and nervous. Khadijah (Ra) took Him to Waraka Ibn Nawfal (the cousin of Khadijah), who had accepted Christianity in the time of ignorance and was able to write the previous divine book in the language of Hebrew. He was also well-versed with the existing divine religions. At that time, $\mathrm{He}$ was an experienced person who had lost his sight. Khadeejah (Ra) said to him, O my cousin, listen to what your nephew says. Waraka said, O my nephew, what you see? After the Prophet completed telling him what he had seen, Waraka said, He is An-Naamoos (Jibril), whom Allah had sent down to Prophet Moosa. I hope that if I were physically powerful! I hope to be alive when your community drives out you from your country. The Prophet said, will they drive out me from my country? Waraka replied, every man when arrived with what you receive, treated them as enemy. If I am alive when the time of yours comes, then I will help you. Waraka died after a short time (Saheeh Bukhari, the beginning of revelation).

She also confirmed him by Waraka Ibn Nawfal that he would be the last Prophet of Allah.

\section{g) Helpful in all kind of righteous activities}

The revelation stopped for a time after the first message revealed. The angel Jibril came to the Prophet Muhammad (saw) for a second time; Allah revealed to Prophet (saw) these verses:

"O you who covers himself (with garments), arise and warn. And your Lord glorify. And your garments purify" (Al-Quran, 74:1-4) 
After the revelation of the second message from Allah, the Prophet (saw) woke up from his sleep. He became worried, anxious, and upset about his duty and responsibility. In this situation, Khadijah (Ra) approached him gently to go back to bed and have some rest and sleep. The Prophet replied the time to relax and sleep is over. Then he informed Khadijah (Ra) that has Jibril commanded him to warn and invite people to Allah and His worship. Then the Prophet said whom I should call? And who is going to accept my invitation? Khadijah (Ra) comforted him by her acceptance of the Prophet Hood of her husband. Thus the Prophet Muhammad (saw) and Khadijah (Ra) striving together in the way of Allah from the beginning of the revelation (Ibn Hisham, ND).

\section{h) Encourage to establish the truth}

Khadijah (Ra) was always loyal and helpful to Prophet Muhammad (saw) mission. She encourages and helped him to preach Islam. In 616, after seven years of revelation, the Quraish started a trade boycott against the Muslims. They attacked, imprisoned, and beat the Muslims. Although Khadijah ( $\mathrm{Ra}$ ) passed her whole life in wealth and luxury, but would not turn away from Allah's Prophet for the pleasure of life. Khadijah (Ra) passed away a short time after the boycott, due to the extreme conditions of the boycott without food and drinks (Ibn Hisham, ND).

i) At a glance the characteristics of Khadijah (Ra) as a model of Muslim women

Khadijah (Ra) was righteous and superwoman; her life is full of lessons for every Muslim woman. The Prophet (saw) described her as "the best amongst the women of this nation." Now some noble character of her mention below at a glance:

- She shared the vision, mission, and ambition of Prophet Muhammad (saw) from her heart as a noble wife.

- She had a good character and qualities that are essential for a superior wife.

- She abstained herself from all kinds of offense that practiced in Arab society. She faced much opposition for staying upright life.

- She was more ahead for racing towards virtue by declared her faith for the first time on the Prophet (saw). As Allah said: "Race towards virtue" (AlQuran, 5: 48).

- She maintains a mutual and understanding relationship with husband

- She was very attentive about the rights of relatives and husband.

- She was a devoted wife. As Allah described in the Quran as a character of a righteous female: Men are in charge of women by what Allah has given one over the other and what they spend on maintenance from their wealth, So virtuous women are devoutly obedient, protector in the husband's absence what Allah would have them guard (Al-Quran, 4:34).

- Her relation was transparent with her husband, Prophet Muhammad (saw). As Allah said in the Quran: they (wife) are clothing for you, and you (husband) are clothing for them (Al-Quran, 2:187).

- Khadijah (Ra) was an excellent mother. She was attentive about her children. She never ignored them.

- She prepared herself for the Akhirat by her efforts and sacrifices.

- She décor the house of Prophet (saw) by her character and disposition.

- Khadijah (Ra) obtained a special place in the heart of the Prophet (saw) by her contribution. None of the wives of the Prophet could acquire this place.

- Khadijah (Ra) was always a constant source of pleasure for her husband.

- She was a respectable, charitable, and wealthy businesswoman who was known and famous for her intelligence, purity, and kindness.

- She was able to balance her family responsibilities and her business.

- She also advocated and supporter of her husband. As Allah said in the Quran:

"The faithful males and females are partner of one another. They command what is right and prohibit what is incorrect and establish prayer and bestow Zakat, and obey Allah and his messenger. Those Allah will have mercy upon them" (Al-Quran, 9: 71).

\section{Vi. Conclusion}

A wife is a husband's helpmate, peer, and partner of life. The wife is the key to the sustainable progress of her husband. A wife holds a variety of positions in the family, such as a leader, administrator, manager of family income, and a mother. The wife of the Prophet Muhammad (saw) Khadijah (Ra) who sacrificed her desire and ambitions, she created an essential environment for her husband, Prophet Muhammad (saw) to think and work more about for the Islam. She was the source of inspiration to her husband, Prophet Muhammad (saw). She stands by him in all the crises as well as she shared with him all achievements and successes. She was that person for whose the Prophet Muhammad (saw) turned to her for love, sympathy, comfort, console, and recognition. She was the symbol of purity, faithfulness, obedience, submission, and devotion to her husband.

\section{References Références Referencias}

1. Al-Quran, 30: 21; 3: 93; 93: 8; 68: 4; 25: 74; 96: 1-5; 74: $1-4$

2. Abul Hasan Al-Balajuri, Ansabul Ashraf, Egypt: Darul Marif, ND. 
3. Al-kandhalubhi, Yusuf, Hayatus Sahaba, Dimuscs: 1983.

4. Ali Khan, Dr. Majid, Muhammad the final Messenger, Pakistan: Sh. Muhammad Ashraf publishers, 1983.

5. Ibn Saad, At-tabakatul Kubra, Bairut: Darul Fikar.

6. Ibn Hisham, As-Sirah An nababiyah, Cairo: 1955.

7. Ibnul Asir, Ali Ibn Muhammad, Usdul Gaba fi Marifatis Sahaba, ND.

8. Ibn Hajar, Shihabuddin Al-askalani, Al-Isaba fi Tamijis Sahaba, Bairut: Darul Fikar, 1978, Vol-4.

9. Muhammad Ali Qutub, Women around the messenger of Allah, International Islamic Publishing House, 2008.

10. Tabari, Muhammad Ibn Jarir, Tarikh al-Rusul wa'lMuluk. Translated by Landau-Tasseron, E. (1998). Vol. 39, Biographies of the Prophet's Companions and Their Successors, p. 161. New York: SUNY Press.

11. https://www.azquotes.com/quote

12. Saheeh Muslim, The book of Nursing; Chapter: The best enjoyment of the world is a righteous wife, Hadeeth number: 1467).

13. Saheeh Bukhaaree, The virtues of the Ansar, Hadith number: 3818, the beginning of revelation Hadeeth number: 3.

14. Saheeh Muslim, Chapter: The virtues of companions, the virtues of Khadeejah, the Mother of the Believers, Hadith number: 2432. 